\title{
Keefektifan Biblioterapi untuk Meningkatkan Resiliensi Siswa Yatim Piatu Penghuni Panti Asuhan
}

\author{
Eem Munawaroh, Afriyadi Sofyan \\ Jurusan Bimbingan dan Konseling, Fakultas Ilmu Pendidikan, Universitas Negeri Semarang \\ Jl. Sekaran, Semarang, Jawa Tengah, Indonesia 50229 \\ E-mail: eemmunawaroh@mail.unnes.ac.id
}

Artikel diterima: 5 Agustus 2018; direvisi: 24 Januari 2019; disetujui: 29 Januari 2019

\begin{abstract}
This study aimed to examine the effectiveness of bibliotherapy to improve three factors of resilience, namely: aspects of I Have; I Am; and I Can, for orphaned students who live in orphanages. The research subjects were 21 orphaned students selected using purposive sampling technique. The quantitative research used the latin square method and statistical analysis paired t-test to analyze the data. The analysis technique of the instrument validity use Spearman. Meanwhile, the analysis technique of instrument reliability used Alpha Cronbach. The results showed that bibliotherapy can significantly improve the three factors of resilience.
\end{abstract}

Keywords: resilience; bibliotherapy; orphan; orphanage

\begin{abstract}
Abstrak: Penelitian ini bertujuan untuk menguji keefektifan biblioterapi untuk meningkatkan tiga faktor resiliensi, yakni: faktor I Have; I Am; dan ICan pada siswa yatim piatu yang tinggal di panti asuhan. Subjek penelitian adalah 21 siswa yatim piatu yang dipilih menggunakan teknik purposive sampling. Penelitian kuantitatif ini menggunakan metode latin square serta analisis statistik paired t test untuk menganalisis data. Teknik analisis validitas instrumen menggunakan Spearman dan analisis reliabilitas instrumen menggunakan Alpha Cronbach. Hasil menunjukkan bahwa biblioterapi mampu meningkatkan ketiga faktor resiliensi.
\end{abstract}

Kata kunci: resiliensi; biblioterapi; yatim piatu; panti asuhan

Siswa panti asuhan adalah anak dibawah 18 tahun yang diambil hak pengasuhannya dari orangtua karena kematian orangtua atau penelantaran (Katyal, 2015). Anak yang berpisah dengan orangtuanya kerap memiliki konsep diri yang rendah (Ahad, Ara, \& Shah, 2016; Gürsoy dkk., 2012); sulit menginternalisasi masalah (Makame, Ani, \& Grantham-McGregor, 2007); serta depresi (Fawzy \& Fouad, 2010). Pada beberapa keadaan, anak yatim piatu tinggal di panti asuhan. Kegiatan di panti asuhan berfokus pada pemenuhan kebutuhan kolektif, khususnya kebutuhan materi seharihari, sementara kebutuhan emosional dan perkembangan kurang diperhatian (Mazaya \& Supradewi, 2019). Kurangnya interaksi dengan keluarga dekat; terbatasnya akses interaksi dengan lingkungan sekitar; dan rendahnya perhatian terhadap kebutuhan emosional serta perkembangan, menyebabkan siswa panti asuhan mudah mengalami stress; kecemasan; dan kesepian (Katyal, 2015). Anak panti asuhan memiliki deskripsi atau gambaran diri sebagai kepribadian yang tertekan; cemas (Zayas, 2018); tidak diakui; tidak lengkap (Taylor, 2010); inferior; pasif; apatis; menarik diri; mudah putus asa; dan penuh ketakutan sehingga sulit menjalin hubungan sosial dengan orang lain (Mazaya \& Supradewi, 2019). Fakta tersebut menjadikan siswa panti asuhan sebagai anak yang rentan mengalami adversitas (Joseph \& Linley, 2004). 
Adversitas mengacu pada pengalaman negatif yang berpotensi mengganggu fungsi adaptif atau perkembangan. Pengalaman terhadap adversitas berdampak pada menurunnya sistem adaptif perkembangan individu dengan konsekuensi yang permanen. Adversitas terbagi ke dalam beberapa jenis: (1) adversitas akut, contohnya bencana alam; (2) adversitas kronis, contohnya dikucilkan dalam pergaulan sehari-hari; (3) adversitas yang muncul dalam lingkungan, contohnya konflik orangtua; kemiskinan; kekerasan; dan (4) adversitas yang berasal dari dalam diri individu seperti penyakit. Pada beberapa level, adversitas berpotensi mengganggu perkembangan dan adaptasi positif individu (Joseph \& Linley, 2004), bahkan pada beberapa kasus, individu yang memiliki adversitas rendah dapat mengalami kondisi medis yang buruk (Santoro, Shear, \& Haber, 2018).

Sebagai salah satu populasi yang hidup dalam keterbatasan dan memiliki trauma emosional, anak panti asuhan cenderung terlibat dalam perilaku anti sosial; kenakalan; dan kriminal (Pharoah, 2016). Anak panti asuhan terutama yang berusia sangat muda memiliki risiko memiliki masalah psikiatrik seperti: gangguan depresi; perilaku; dan emosional di kemudian hari. Sebuah penelitian cross sectional mengenai prevalensi depresi pada 180 anak panti asuhan usia 12-18 tahun menunjukkan bahwa depresi adalah gangguan psikiatrik yang umum terjadi pada anak panti asuhan, khususnya perempuan. Identifikasi dan intervensi awal sangat diperlukan untuk mencegah munculnya konsekuensi lebih lanjut (Ramagopal, Narasimhan, \& Devi, 2016).

Anak panti asuhan memiliki kapasitas yang berbeda dalam menghadapi kemalangan hidupnya. Ada anak yang mampu bertahan dan pulih dari adversitas yang pernah dialaminya, ada pula anak yang gagal karena tidak berhasil keluar dari situasi yang tidak menguntungkan. Kemampuan untuk melanjutkan hidup setelah ditimpa kemalangan atau bertahan di tengah lingkungan dengan tekanan bukanlah kemampuan yang datang secara otomatis. Kondisi tersebut menunjukkan adanya kemampuan tertentu dalam diri individu yang dikenal dengan istilah resiliensi (Tugade \& Fredrickson, 2004). Secara umum, resiliensi merupakan suatu kemampuan yang dimiliki oleh seseorang atau suatu komunitas yang meningkatkan kemampuan untuk menghadapi dan mengatasi permasalahan (Prihastuti, 2013).

Faktor-faktor resiliensi yang diidentifikasi berdasarkan sumber-sumber yang berbeda adalah: I Have; I Am; dan I Can (Grotberg, 1999). I Have merupakan faktor pembentuk resiliensi yang menggambarkan dukungan eksternal dalam meningkatkan resiliensi. I Am merupakan faktor resiliensi yang menunjukkan kekuatan yang berasal dari dalam diri individu. I Can adalah kemampuan yang dimiliki individu untuk mengungkapkan perasaan dan pikiran dalam berkomunikasi dengan orang lain.

Salah satu strategi intervensi yang telah banyak digunakan untuk mengembangkan resiliensi adalah terapi kognitif. Mengacu berbagai hasil penelitian, terapi kognitif telah terbukti dapat mengembangkan resiliensi. Interpersonal Cognitive Problem Solving (ICPS) telah terbukti dapat digunakan untuk membantu individu mengatasi tekanan; frustasi; dan kegagalan dalam hidup (Goldstein \& Brooks, 2005). ICPS mampu mengembangkan resiliensi anak yang memiliki adversitas melalui simulasi ilustrasi kesulitan sehari-hari. Penelitian lain terkait pendekatan kognitif yang mampu meningkatkan resiliensi adalah teknik restrukturisasi kognitif (Antara, Antari, \& Dantes, 2014).

Biblioterapi yang merupakan terapi dengan penggunaan buku sebagai media adalah bagian penting dalam terapi kognitif, yakni sebagai self help tool (Purwanto, 2015). Buku dapat membantu individu dalam mempelajari fakta baru, cara pandang yang berbeda dalam menghadapi masalah, dan alternatif pemecahan masalah (Herlina, 2013). Berbagai hasil penelitian menunjukkan efek positif biblioterapi, yakni: menurunkan gangguan kecemasan (Campbell, 2007); mencegah gangguan kesehatan mental; membantu proses adaptasi individu; mengembangkan kemampuan bangkit dari keterpurukan (Rutten dkk., 2013); serta meningkatkan kesehatan mental (Bilich, Deane, Phipps, Barisic, \& Gould, 2008).

Penelitian terdahulu lebih fokus menjelaskan keefektifan teknik biblioterapi dalam berbagai konteks klinis (Popa \& Porumbu, 2017). Perkembangan terbaru mengenai adversitas yang terjadi di lingkungan sosial, terdapat populasi khusus yang rentan dan memerlukan resiliensi sebagai salah 
satu kompetensi dalam menjalani hidup. Siswa yatim piatu yang tinggal di panti asuhan merupakan populasi khusus tersebut dan mereka memerlukan life skills untuk menghadapi adversitas serta berkembang secara optimal (Hamid, Tolla, Jufri, \& Jokebet, 2018). Artikel ini akan membahas tentang keefektifan teknik biblioterapi sebagai salah satu teknik intervensi untuk mengembangkan resiliensi sebagai kecakapan hidup siswa yatim piatu yang tinggal di panti asuhan.

\section{METODE}

Pendekatan yang digunakan dalam penelitian ini adalah pendekatan kuantitatif dengan metode eksperimen desain latin square jenis within-subject (Heppner, Kivlighan Jr, \& Wampold, 2008). Desain ini dipilih untuk menjamin bahwa biblioterapi untuk meningkatkan resiliensi siswa yatim piatu penghuni panti asuhan disajikan secara seimbang dengan frekuensi yang sama. Populasi dalam penelitian ini adalah 60 orang siswa yatim piatu yang tinggal di panti asuhan Wisma Putra. Sampel dalam penelitian ini diambil secara purposif. Sampel adalah semua siswa yang memiliki tingkat resiliensi rendah. Untuk mengetahui siswa yang memiliki resiliensi rendah, peneliti menggunakan instrumen resiliensi. Berdasarkan pengukuran instrumen resiliensi, diketahui ada 21 siswa yang masuk pada kategori resiliensi rendah.

Penelitian ini menggunakan tiga instrumen resiliensi yakni instrumen I Have, I Am, dan I Can. Ketiga instrumen tersebut menggunakan Skala Likert dengan pilihan jawaban partisipan dimulai dari Sangat Setuju (SS) dengan bobot 4; Setuju (S) dengan bobot 3; Tidak Setuju (TS) dengan bobot 2; dan Sangat Tidak Setuju (STS) dengan bobot 1. Alasan penggunaan instrumen dengan Skala Likert adalah karena Skala Likert mampu mengungkap tingkat resiliensi secara lebih terperinci dan jelas.

Uji validitas instrumen menggunakan Pearson Product Moment dan uji reliabilitas instrumen rumus Alpha Cronbach. Berdasarkan uji validitas instrumen, terdapat beberapa butir dari ketiga instrumen yang tidak valid, butir tersebut diperbaiki sehingga menjadi butir yang valid. Berdasarkan uji reliabilitas instrumen, skor reliabilitas masing-masing instrumen adalah I Have $(0,79) ;$ I Am $(0,81)$; dan I Can $(0,75)$. Berdasarkan kategori koefisien reliabilitas dari Guilford (1950) maka reliabilitas instrumen I Have berada pada kategori tinggi, I Am berada pada kategori sangat tinggi, dan I Can berada pada kategori tinggi. Teknik analisis Uji t berpasangan (paired $t$-test) digunakan sebagai teknik analisis data karena mampu menguji perbedaan rata-rata antara dua kelompok sampel yang berpasangan.

Intervensi biblioterapi untuk meningkatkan resiliensi dilaksanakan dalam empat tahapan yakni: identifikasi, seleksi, presentasi dan follow up. Pada tahap identifikasi, dilakukan identifikasi terhadap kebutuhan subjek terkait faktor resiliensi yang dikembangkan. Pada tahap seleksi peneliti memilih tiga jenis novel yakni: Sepatu Dahlan karya Khrisna Pabichara; Surat Kecil untuk Tuhan karya Agnes Davonar; dan Ibuk karya Iwan Setiawan. Novel-novel tersebut menggambarkan perjuangan para tokoh dalam menghadapi penderitaan hidup dan proses kebangkitan dari kemalangan yang dideritanya. Pemilihan buku tersebut sesuai dengan variabel resiliensi yang akan dikembangkan. Pada tahap presentasi, subjek diminta membaca buku dalam kurun waktu seminggu sesuai kesepakatan dengan konselor. Selama membaca buku, subjek mengisi form identifikasi cerita yang mengungkap isi novel seperti karakteristik tokoh; emosi yang muncul ketika tokoh mengalami kemalangan; dan bagaimana tokoh bangkit dari tekanan yang dialaminya. Pada tahap follow up, subjek mengikuti konseling kelompok dengan materi form identifikasi cerita buku sebagai bahan konseling kelompok. Subjek dibagi menjadi tiga kelompok, yang tiap kelompok terdiri dari tujuh subjek. Kelompok tersebut adalah kelompok A; B; dan C. Setiap kelompok subjek mendapatkan intervensi biblioterapi sebanyak 3 kali menggunakan buku Surat Kecil untuk Tuhan, Ibuk, dan Sepatu Dahlan dengan jeda 1 minggu. Urutan dan jenis intervensi biblioterapi secara rinci untuk masing-masing kelompok subjek disajikan dalam tabel 1.

Tahapan konseling kelompok yang dilaksanakan meliputi tahap awal, tahap transisi, dan tahap akhir. Pada tahap awal, kegiatan inti yang dilaksanakan yaitu setiap anggota kelompok menceritakan adversitas dan kesulitan yang dialaminya. Pada tahap transisi, setiap anggota kelompok memberikan 
Tabel 1 Rancangan Penelitian Latin Square

\begin{tabular}{clll}
\hline \multirow{2}{*}{ Kelompok Subjek } & \multicolumn{3}{c}{ Faktor Resiliensi } \\
\cline { 2 - 4 } & \multicolumn{1}{c}{ I Have } & \multicolumn{1}{c}{$\boldsymbol{I} \boldsymbol{A m}$} & \multicolumn{1}{c}{ I Can } \\
\hline A & Surat kecil untuk Tuhan & Ibuk & Sepatu Dahlan \\
B & Ibuk & Sepatu Dahlan & Surat kecil untuk Tuhan \\
C & Sepatu Dahlan & Surat kecil untuk Tuhan & Ibuk \\
\hline
\end{tabular}

masukan dalam menghadapi adversitas yang dialami berdasarkan pengalaman masing-masing anggota. Pada tahap akhir, setiap anggota kelompok mengidentifikasi dan menginternalisasi berbagai alternatif masukan yang sesuai dengan adversitas yang dialami.

\section{HASIL}

Setelah subjek diberi intervensi biblioterapi, tahap selanjutnya adalah menguji keefektifan biblioterapi terhadap resiliensi melalui uji paired t test yang hasilnya disajikan dalam tabel 2. Hasil uji paired t test keefektifan teknik biblioterapi terhadap resiliensi menunjukkan bahwa nilai sig. (2-tailed) $0,000<0,05$. Karena nilai signifikansi 0,000 lebih kecil dari 0,05, maka dapat diketahui bahwa teknik biblioterapi dapat meningkatkan faktor resiliensi I Have; I Am; dan I Can secara signifikan. Pada Faktor I Have, faktor yang ditingkatkan adalah kepercayaan terhadap hubungan dan kepercayaan terhadap role model. Pada faktor I Am, faktor yang ditingkatkan adalah: perasaan dicintai; mencintai; empati; altruis; kebanggaan pada diri sendiri; kemandirian; tanggung jawab; harapan; dan keyakinan. Pada Faktor I Can, kemampuan yang ditingkatkan adalah: kemampuan komunikasi; pemecahan masalah; pengelolaan emosi dan kemampuan menjalin hubungan dengan orang lain.

Keefektifan biblioterapi dalam mengembangkan resiliensi subjek didukung oleh beberapa faktor, salah satunya adalah pemilihan materi biblioterapi yang sesuai dengan adversitas subjek. Ketiga buku yang digunakan sebagai materi biblioterapi menggambarkan kondisi tokoh yang menghadapi kemalangan yakni kemiskinan dan penyakit. Persamaan latar belakang cerita dan kondisi yang dihadapi subjek menjadi salah satu faktor ketertarikan subjek terhadap materi biblioterapi. Selanjutnya, subjek diberikan keleluasaan waktu untuk membaca buku, sehingga subjek dengan leluasa dapat menghayati dan memahami isi buku serta menginternalisasi nilai-nilai yang ada dalam buku tersebut.

Tabel 2 Hasil Uji Paired T Test Biblioterapi Terhadap Resiliensi

\begin{tabular}{ccccccc}
\hline Resiliensi & Mean & Standar Deviasi & T Hitung & T Tabel & Sig & Keterangan \\
\hline I Have & 15,00 & 3,91 & 10,135 & 1,943 & 0,000 & Signifikan \\
I Am & 18,43 & 4,65 & 10,486 & 1,943 & 0,000 & Signifikan \\
I Can & 34,14 & 13,04 & 6,925 & 1,943 & 0,000 & Signifikan \\
\hline
\end{tabular}

\section{PEMBAHASAN}

Terdapat beberapa kelebihan buku dalam membantu subjek meningkatkan resiliensi. Cerita dalam buku menampilkan nilai-nilai universal, yakni kemampuan buku untuk menampilkan kisah yang memiliki kesamaan dengan kisah yang dialami subjek. Nilai-nilai tersebut dapat menimbulkan pemahaman bahwa subjek bukanlah satu-satunya orang yang memiliki atau mengalami kemalangan. Rasa universal dapat memberikan kekuatan kepada pembaca buku untuk menghadapi kesulitan yang dihadapi. Kelebihan lain yang terdapat dalam buku adalah coping yang ditunjukkan oleh tokoh dalam cerita memberikan pembaca alternatif coping. Cerita dalam buku dapat menjadi media dalam mengungkapkan tekanan emosi dan mental; mengembangkan konsep diri individu; dan mengkomunikasikan nilai serta sikap baru. Faktor-faktor tersebut dapat meningkatkan resiliensi siswa yatim piatu yang tinggal di panti asuhan (Tukhareli, 2011). 
Dalam proses biblioterapi, konselor dan subjek mengidentifikasi berbagai alternatif solusi atau tindakan yang ditunjukkan oleh tokoh dalam cerita novel dan menginternalisasinya ke dalam masalah yang dialami subjek. Selanjutnya, konselor dan subjek mendiskusikan masalah yang dialami subjek dengan penuh keterbukaan. Topik lain yang didiskusikan dalam konseling kelompok adalah keterampilan menyelesaikan masalah sebagaimana ditunjukkan oleh tokoh dalam cerita. Sesi terakhir merupakan sesi mengembangkan konsep diri partisipan dengan mendiskusikan bagaimana tokoh dalam novel mengembangkan diri setelah kemalangan yang dialaminya (Maich \& Kean, 2004).

Intervensi biblioterapi mampu meningkatkan resiliensi pada faktor I Have melalui peningkatan kepercayaan terhadap hubungan dan kepercayaan terhadap role model. Ketiga novel yang digunakan sebagai media biblioterapi menggambarkan kuatnya hubungan tokoh dengan orang-orang di sekitarnya, seperti orangtua dan teman-teman. Selain itu, digambarkan bagaimana tokoh dalam novel meneladani karakteristik positif orang-orang di sekitarnya. Hubungan yang erat dan keteladanan dengan significant other tersebut memberikan kekuatan kepada tokoh untuk menghadapi kesulitan dalam hidupnya. Dalam konseling kelompok, keteladanan significant other tersebut diinternalisasi melalui identifikasi terhadap significant other subjek dan identifikasi sikap-sikap positif yang dapat dicontoh dari significant other. Significant other berkorelasi dengan self-direct dan self-regulation dan memiliki implikasi terhadap perkembangan resiliensi (Andersen, Chen, \& Miranda, 2002).

Pada faktor $I A m$, biblioterapi dapat meningkatkan perasaan dicintai; mencintai; empati; altruis; kemandirian; tanggung jawab; harapan; keyakinan; dan kepercayaan. Nilai-nilai tersebut diinternalisasi oleh subjek melalui identifikasi terhadap dinamika cerita dalam novelyang diungkapkan kembali saat sesi konseling kelompok. Bacaan fiksi memiliki pengaruh pada rasa empati, alur cerita dalam buku fiksi dapat mengubah empati pembacanya (Bal \& Veltkamp, 2013). Selain bacaan fiksi, salah satu hasil penelitian lain menunjukkan bahwa literatur anak efektif membantu mahasiswa untuk mengetahui pandangan pribadi dalam meningkatkan kualitas hubungan dengan orang lain (Bouley \& Godfrey, 2008).

Pada faktor I Can, biblioterapi mampu mengembangkan kemampuan komunikasi; pemecahan masalah; pengelolaan emosi dan kemampuan menjalin hubungan dengan orang lain. Alur cerita dalam novel Ibuk; Surat Kecil untuk Tuhan; dan Sepatu Dahlan menyajikan cerita tentang bagaimana tokoh utama membuat berbagai alternatif pemecahan masalah dan menunjukkan pengelolaan emosi saat berada dalam kesulitan. Subjek mengidentifikasi keterampilan tersebut dan menginternalisasinya selama proses membaca dan pada saat konseling kelompok.

Salah satu keuntungan biblioterapi adalah dapat mereduksi emosi negatif dan menggantinya dengan perilaku dan perasaan yang lebih positif (Pehrsson, Allen, Folger, McMillen, \& Lowe, 2007). Membaca buku, efektif dalam: meningkatkan kemampuan pemecahan masalah; meningkatkan perasaan terharu; mengembangkan empati; dan meningkatkan kesadaran diri. Biblioterapi memiliki efek sangat signifikan terhadap faktor I Can yang berisi kemampuan komunikasi; penyelesaian masalah; kontrol emosi; dan kemampuan membangun hubungan yang terpercaya dengan orangorang sekitar.

Faktor I Solve dapat meningkatkan kemampuan individu dalam menyelesaikan masalah (Forgan, 2002). I Solve dapat digunakan Konselor dalam membimbing siswa untuk menguasai keterampilan pemecahan masalah melalui biblioterapi. I dalam I Solve adalah identify the problem (mengidentifikasi masalah) yang ada dalam sebuah buku. $S$ adalah solution (solusi), yakni individu mengidentifikasi berbagai alternatif solusi yang dilakukan oleh tokoh dalam buku yang dibaca. $O$ adalah obstacle (hambatan), yakni individu mengidentifikasi berbagai hambatan dalam proses penyelesaian masalah. $L$ adalah looking, yakni individu melihat kembali alternatif pemecahan masalah dan memilih salah satunya sebagai pemecahan masalah yang terbaik. $V$ adalah very good, yakni individu mengatakan terhadap diri sendiri keberhasilan dan yang telah dilakukan dalam pemecahan masalah. Yang terakhir adalah $E$ yakni evaluation, individu dibantu oleh konselor mengevaluasi keefektifan solusi terhadap masalah. 
Pendekatan I Solve dalam membaca buku mampu meningkatkan kemampuan siswa dalam memecahkan masalah, karena membaca buku dengan metode I Solve dapat menunjukkan dan meningkatkan hal-hal: (1) menunjukkan terhadap siswa bahwa dia bukanlah satu-satunya orang yang mengalami masalah tersebut; (2) membantu siswa mendiskusikan masalahnya secara bebas; (3) membantu individu merencanakan solusi yang konstruktif terhadap masalahnya; (4) mengembangkan konsep diri individu; (5) melepaskan tekanan emosi dan mental; (6) meningkatkan pemahaman individu terhadap orang lain

Pemecahan masalah yang ada dalam cerita dapat mengubah cara siswa berinteraksi dan memperlakukan orang lain. Dengan mengidentifikasi karakter dalam novel, siswa memahami bahwa merekatidaklah sendirian dalam menghadapi masalah. Dalam sesi konseling, konselimengembangkan pemahaman terhadap masalah yang dialami oleh tokoh dalam cerita, mengidentifikasi berbagai akar permasalahan yang muncul dan mengidentifikasi berbagai kemungkinan dampak yang akan muncul dari masalah tersebut.

Buku "Feeling Good" menjelaskan teori dasar kognitif untuk penderita depresi (Moldovan, Cobeanu, \& David, 2013). Buku ini memiliki enam bab, di antaranya adalah bab yang berjudul "pahami suasana hati, perasaan, dan cara berpikirmu"; "mengalahkan rasa bersalah"; dan "cara-cara untuk mengatasi prokrastinasi". Treatment dilaksanakan selama satu bulan, dan setiap satu minggu selama lima menit, konselor menelepon partisipan untuk mendiskusikan berbagai pertanyaan mengenai bacaan. Perubahan yang terjadi pada partisipan di antaranya adalah partisipan memiliki perasaan yang lebih baik. Biblioterapi memang efektif untuk membantu anak yang memiliki gangguan emosi dan perilaku (Akinola, 2014).

Keefektifan biblioterapi dalam meningkatkan resiliensi siswa yatim piatu yang tinggal di panti asuhan dipengaruhi oleh beberapa faktor, di antaranya oleh minat baca dan motivasi subjek untuk berubah. Subjek yang memiliki minat baca tinggi akan dengan seksama memahami setiap bagian bacaan dan melibatkan faktor emosi dan kognisi ketika membacanya. Sebagai contoh, pembaca membayangkan dirinya menjadi tokoh dalam cerita tersebut dalam menghadapi situasi sulit. Subjek juga dapat membayangkan alternatif solusi yang paling sesuai dengan masalah yang dihadapinya. Individu yang rasional dan reflektif akan mengalami proses biblioterapi yang efektif (Purwanto, 2015).

\section{SIMPULAN}

Teknik biblioterapi mampu meningkatkan faktor resiliensi I Am, I Have, dan I Can secara signifikan. Biblioterapi mampu mengembangkan: kemampuan berkomunikasi; menyelesaikan masalah; pengelolaan emosi; altruis; kebanggaan pada diri sendiri; tanggung jawab; dan kemandirian. Implikasi penelitian ini terhadap bimbingan dan konseling adalah biblioterapi dapat dijadikan salah satu alternatif strategi intervensi oleh konselor untuk membantu konseli bangkit dari kemalangan yang dihadapinya. Biblioterapi juga dapat dijadikan alternatif strategi intervensi untuk mengembangkan kemampuan berkomunikasi; menyelesaikan masalah; pengelolaan emosi; mengembangkan altruis; dan tanggung jawab.

\section{DAFTAR RUJUKAN}

Ahad, R., Ara, S., \& Shah, S. A. (2016). Self-Concept and Aggression among Institutionalised Orphans of Kashmir. The International Journal of Indian Psychology, 3(2), 104-116.

Akinola, A. N. (2014). Bibliotherapy as An Alternative Approach to Children's Emotional Disorders. Creative Education, 5(14), 1281-1285. https://doi.org/10.4236/ce.2014.514146

Andersen, S. M., Chen, S., \& Miranda, R. (2002). Significant Others and The Self. Self and Identity, l(2), 159-168.

Antara, I. N. K. T., Antari, N. N. M., \& Dantes, N. (2014). Penerapan Konseling Kognitif dengan Teknik Restrukturisasi Kognitif untuk Meningkatkan Resiliensi Siswa Kelas XI IPA 1 SMA Negeri 3 Singaraja. Jurnal Ilmiah Bimbingan Konseling Undiksha, 2(1). 
Bal, P. M., \& Veltkamp, M. (2013). How Does Fiction Reading Influence Empathy? An Experimental Investigation on the Role of Emotional Transportation. PLOS ONE, 8(1), e55341. https://doi. org/10.1371/journal.pone.0055341

Bilich, L. L., Deane, F. P., Phipps, A. B., Barisic, M., \& Gould, G. (2008). Effectiveness of Bibliotherapy Self-help for Depression with Varying Levels of Telephone Helpline Support. Clinical Psychology \& Psychotherapy: An International Journal of Theory \& Practice, 15(2), 61-74.

Bouley, T. M., \& Godfrey, P. C. (2008). Reading Outside the Boundaries: Children's Literature as Pedagogy for Building Empathy and Understanding of Social Justice in the College Classroom. Journal of Effective Teaching, 8(1), 33-41.

Campbell, M. A. (2007). Don't Worry: Promoting Resilience Through The Use of Books in The Classroom. Primary and Middle Years Educator, 5(1), 3-8.

Fawzy, N., \& Fouad, A. (2010). Psychosocial and Developmental Status of Orphanage Children: Epidemiological Study. Current Psychiatry, 17(2), 41-48.

Forgan, J. W. (2002). Using Bibliotherapy to Teach Problem Solving. Intervention in School and Clinic, 38(2), 75-82.

Goldstein, S., \& Brooks, R. B. (2005). Resilience in Children. Springer.

Grotberg, E. H. (1999). Inner strength: How to Find The Resilience to Deal With Anything. California. New Harbinger Publication Ltd.

Guilford, J. P. (1950). Fundamental Statistics in Psychology and Education.

Gürsoy, F., Biçakçi, M. Y., Orhan, E., Bakırcı, S., Çatak, S., \& Yerebakan, Ö. (2012). Study on SelfConcept Levels of Adolescents in the Age Group of 13-18 Who Live in Orphanage and Those Who do not Live in Orphanage. International Journal of Social Sciences \& Education, 2(1).

Hamid, S., Tolla, I., Jufri, M., \& Jokebet, J. (2018). The Development Of Vocaltional and Life Skills Training for Orphans Competency. IOSR Journal of Research \& Method in Education (IOSRJRME), 8(2), 15-21.

Heppner, P. P., Kivlighan Jr, D. M., \& Wampold, B. E. (2008). Research Design in Counseling. Belmont, CA, US: Thomson Brooks/Cole Publishing Co.

Herlina. (2013). Bibliotherapy: Mengatasi Masalah Remaja dan Anak Melalui Buku. Bandung: Pustaka Cendekia Press.

Joseph, S., \& Linley, P. A. (2004). Positive Therapy: A Positive Psychological Theory of Therapeutic Practice. Positive Psychology in Practice, 354-368.

Katyal, S. (2015). A Study of Resilience in Orphan and Non-orphan Children. International Journal of Multidisciplinary Research and Development, 2(7), 323-327.

Maich, K., \& Kean, S. (2004). Read Two Books and Write Me in the Morning! Bibliotherapy for Social Emotional Intervention in the Inclusive Classroom. TEACHING Exceptional Children Plus, 1(2).

Makame, V.,Ani, C., \& Grantham-McGregor, S. (2007). Psychological Well-being of Orphansin DarEl Salaam, Tanzania. Acta Paediatrica, 91(4), 459-465. https://doi.org/10.1111/j.1651-2227.2002. tb01671.x

Mazaya, K. N., \& Supradewi, R. (2019). Konsep Diri dan Kebermaknaan Hidup pada Remaja di Panti Asuhan. Proyeksi, 6(2), 103-112.

Moldovan, R., Cobeanu, O., \& David, D. (2013). Cognitive Bibliotherapy for Mild Depressive Symptomatology: Randomized Clinical Trial of Efficacy and Mechanisms of Change. Clinical Psychology \& Psychotherapy, 20(6), 482-493.

Pehrsson, D.-E., Allen, V. B., Folger, W. A., McMillen, P. S., \& Lowe, I. (2007). Bibliotherapy with Preadolescents Experiencing Divorce. The Family Journal, 15(4), 409-414. 
Pharoah, R. (2016). AIDS, Orphan and Crime: Exploring The Linkages. South African Crime Quarterly, 13, 7-14. https://doi.org/10.17159/2413-3108/2005/v0i13a1010

Popa, D., \& Porumbu, D. (2017). Bibliotherapy in Clinical Context: An Umbrella Review. Transilvania University of Brasov. Series VII, Social Sciences, Law., 10(2), 165-174.

Prihastuti, P. (2013). Profil Resiliensi Pendidik Berdasarkan Resilience Quetient Test. Jurnal Penelitian dan Evaluasi Pendidikan, 15(2), 199-214.

Purwanto, E. (2015). Pengaruh Bibliotherapy terhadap Psychological Well-being Perempuan Lajang. CALYPTRA, 4(1), 1-26.

Ramagopal, G., Narasimhan, S., \& Devi, L. U. (2016). Prevalence of Depression among Children Living in Orphanage. International Journal of Contemporary Pediatrics, 3(4), 1326-1328.

Rutten, B. P. F., Hammels, C., Geschwind, N., Menne-Lothmann, C., Pishva, E., Schruers, K., ... Wichers, M. (2013). Resilience in Mental Health: Linking Psychological and Neurobiological Perspectives. Acta Psychiatrica Scandinavica, 128(1), 3-20.

Santoro, A. F., Shear, S. M., \& Haber, A. (2018). Childhood Adversity, Health and Quality of Life in Adults with Intellectual and Developmental Disabilities. Journal of Intellectual Disability Research, 62(10), 854-863. https://doi.org/10.1111/jir.12540

Taylor, S. E. (2010). The Childhood Experience of Being a War Orphan: A Study of the Effects of Father Loss on Women Whose Fathers Were Killed in World War II. Journal of Loss and Trauma, 15(3), 228-241. https://doi.org/10.1080/15325020903381709

Tugade, M. M., \& Fredrickson, B. L. (2004). Resilient Individuals Use Positive Emotions to Bounce Back from Negative Emotional Experiences. Journal of Personality and Social Psychology, $86(2), 320-333$.

Tukhareli, N. (2011). Bibliotherapy in a Library Setting: Reaching Out to Vulnerable Youth. Partnership: The Canadian Journal of Library and Information Practice and Research, 6(1), 1-18. https://doi.org/10.21083/partnership.v6i1.1402

Zayas, L. H. (2018). Immigration Enforcement Practices Harm Refugee Children and CitizenChildren. Zero To Three, 38(3), 20-25. 